\title{
Rancangan Sistem Informasi Website Pembayaran Zakat Online dalam Menghadapi Situasi Wabah Covid-19
}

\author{
Yudiman Abdul Hidayat \\ Telkom University; \\ Email: yudimanhidayat@telkomuniversity.ac.id
}

\begin{abstract}
Zakat secara bahasa artinya bersih atau suci. Secara istilah zakat merupakan sebagian harta yang wajib dikeluarkan oleh orang yang beragama Islam. Zakat tersebut akan disalurkan kepada orang-orang yang berhak menerimanya. Namun dalam situasi sekarang ini dengan adanya pandemi wabah covid-19 atau virus corona, masyarakat mengalami kesulitan dalam melakukan pembayaran zakat. Sehingga potensi orang-orang yang akan membayar zakat cenderung akan menurun dikarenakan adanya kasus pandemi ini. Maka dari itu diperlukanlah suatu rancangan sistem informasi yang dapat memudahkan masyarakat dalam melakukan pembayaran zakat tanpa harus datang ke masjid atau DKM secara langsung. Salah satunya dengan menciptakan sistem pembayaran zakat online melalui sebuah website.
\end{abstract}

Keywords: zakat, covid-19, online, website

\section{Introduction}

1.1. Business case

Adanya kasus pandemi covid-19 atau virus corona telah merusak segala aktivitas masyarakat Indonesia bahkan di seluruh negara. Tidak hanya merusak kesehatan, adanya pandemi ini juga merusak perekonomian, pendidikan, dan bahkan merusak kegiatan peribadahan berbagai agama. Salah satunya adalah dalam agama Islam, yang biasanya dipenghujung bulan Ramadhan umat Islam diseluruh dunia akan melakukan rukun Islam yang ke empat yaitu melakukan pembayaran zakat fitrah. Pembayaran zakat fitrah tersebut bersifat wajib bagi seluruh umat Islam.

Akan tetapi dengan adanya wabah covid-19 ini, diprediksi jumlah orang yang membayar zakat akan menurun. Salah satu penyebabnya karena proses pembayaran zakat di negara Indonesia masih secara tradisional, yaitu dengan cara mendatangi langsung masjid, DKM atau panitia zakat diberbagai daerah untuk melakukan pembayaran zakat. Dan dalam situasi sekarang ini pemerintah menerapkan PSBB (Pembatasan Sosial Berskala Besar) yang membatasi pergerakan dan kegiatan masyarakat. Maka dari itu, salah satu cara untuk mengantisipasi menurunnya jumlah orang yang melakukan pembayaran zakat dengan cara menciptakan suatu rancangan website pembayaran zakat secara online. Website pembayaran zakat tersebut bisa diakses dirumah masing-masing dan dapat mudah digunakan. Sehingga diharapkan dengan adanya pembayaran zakat secara online tersebut dapat meningkatkan jumlah orang yang melakukan pembayaran zakat. Dikarenakan pembayaran zakat secara online prosesnya tidak perlu datang secara langsung ke masjid atau DKM panitia pembayaran zakat. Program tersebut juga sangat mendukung pemerinah dalam menghadapi pandemi covid-19 ini.

\subsection{System Requirement}

Rancangan website pembayaran zakat online ini memiliki fungsi untuk memudahkan masyarakat yang ingin melakukan pembayaran zakat tanpa harus mendatangi langsung tempat pembayaran zakat. Akan tetapi pembayaran zakat tersebut bisa dilakukan dimana saja termasuk dari rumah. Sehingga bisa menghemat waktu, tenaga, dan mendukung program pemerintah dalam situasi 
menghadapi wabah covid-19 ini. Diharapkan juga dengan adanya system website pembayaran zakat secara online ini, bisa meningkatkan jumlah orang yang membayar zakat.

Rancangan website pembayaran zakat online ini memiliki memiliki beberapa fitur diantaranya terdapat menu info zakat yang berfungsi untuk memberikan informasi mengenai zakat. Selain itu terdapat fitur cara pembayaran zakat secara online untuk membantu memudahkan pembayar zakat dalam melakukan pembayaran melalui website tersebut. Selain itu dalam rancangan website ini terdapat fitur data penerima zakat, untuk mengetahui rumah dan siapa saja yang berhak menerima zakat tersebut.

\section{Penjelasan SIngkat Terkait Metode}

Waterfall merupakan salah satu metode dalam pengembangan sistem informasi yang bersifat sistematis dan sekuensial, yang berarti setiap tahapan dalam metode tersebut dilakukan secara berurutan dan berkelanjutan. Berikut merupakan tahapan dari metode waterfall:

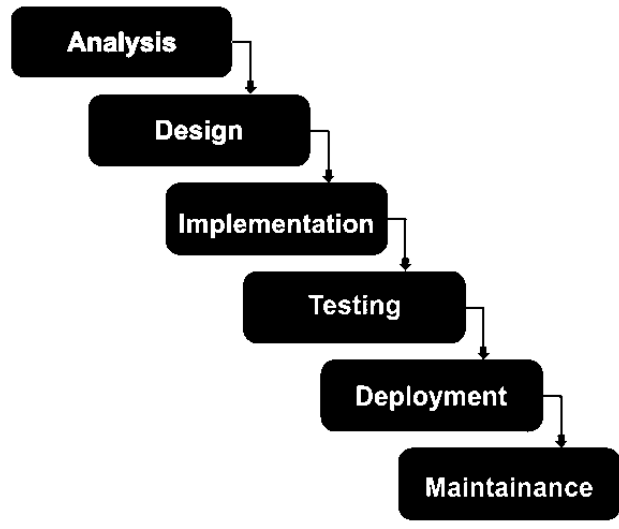

Figure 1 Tahapan waterfall

Tahap analisis merupakan tahap mengumpulkan kebutuhan yang kemudian dianalisis dan didefinisikan kedalam kebutuhan yang harus dipenuhi oleh program yang akan dubangun. Kemudian tahap desain yaitu tahap pegembangan yang menghasilkan sebuah system. Selanjutnya tahap implementasi yaitu tahap dimana desain diubah ke dalam bentuk kode program. Testing merupakan penggabungan modul-modul yang selanjutnya dilakukan pengujian. Selanjutnya deployment merupakan pengujian apakah system tersebut sudah sesuai dengan yang disetujui. Dan terakhir maintainance yaitu tahap proses perbaikan sistem yang disetujui.

\section{Proses Perhitungan}

\subsection{System Design}

\subsubsection{Business Requirement}

Analisis Stakeholder

Stakeholder dalam system informasi pembayaran zakat online ini merupakan masyarakat yang memiliki keterkaitan dengan kegiatan pembayaran zakat. Adapun system website ini diciptakan untuk mempermudah dalam transaksi pembayaran zakat di masjid atau DKM setempat.
a. Owner: CEO website pembayaran zakat "Al-AminZakat.com"
b. User: Admin (DKM atau pengurus), panitia zakat
c. Customer: masyarakat pembayar zakat melalui "Al-AminZakat.com"
d. Analyst: tim analyst website "Al-AminZakat.com"

Analisis User Role

a. Admin: mengurus semua transaksi pembayaran zakat

b. Panitia zakat: mengatur penyaluran zakat 


\subsection{Data Flow Diagram (DFD)}

c. Analyst: melakukan pengembangan dan perbaikan website

Data flow diagram atau bisa disebut juga dengan diagram alir data merupakan suatu diagram yang menggunakan notasi-notasi untuk menggambarkan proses kerja suatu sistem. Berikut merupakan data flow diagram level 0 dari rancangan website pembayaran zakat online:

Data Flow Diagram Level 0

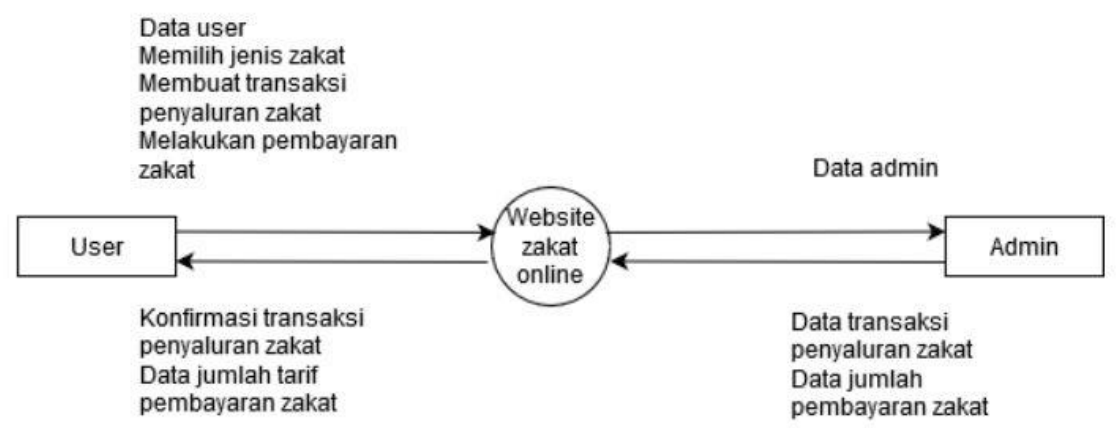

Figure 2 Data Flow Diagram Level 0

Berikut merupakan data flow diagram level 1 dari rancangan website pembayaran zakat online:

Data Flow Diagram Level 1

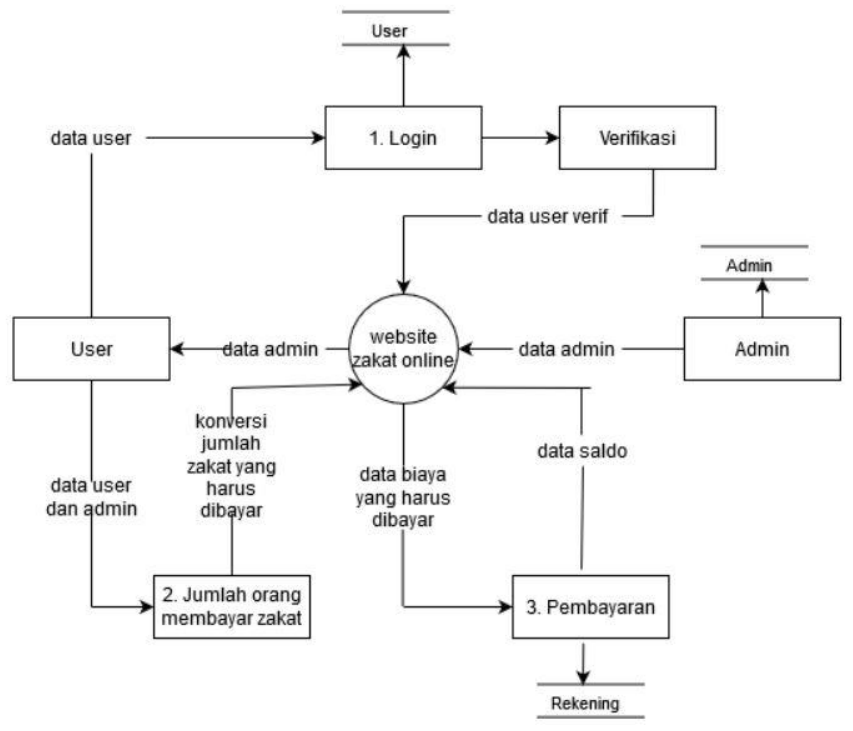

Figure 3 Data Flow Diagram Level 1

Berikut merupakan data flow diagram level 2 menu login dari rancangan website pembayaran zakat online: 
Data Flow Diagram Level 2 Login

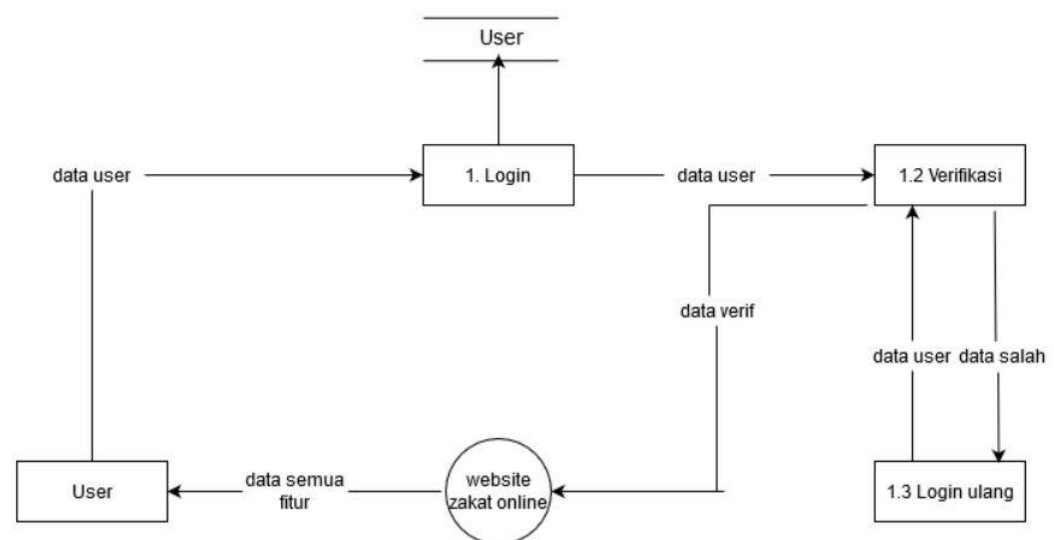

Figure 4 Data Flow Diagram Level 2 Login

Berikut merupakan data flow diagram level 2 proses pembayaran dari rancangan website pembayaran zakat online:

Data Flow Diagram Level 2 Pembayaran

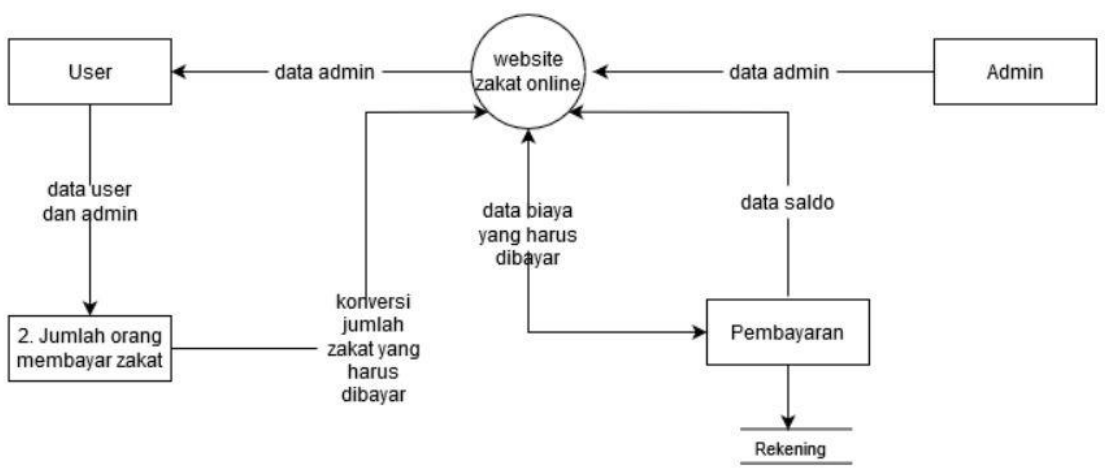

Figure 5 Data Flow Diagram Level 2 Pembayaran

\subsection{Entity Relationship Diagram (ERD)}

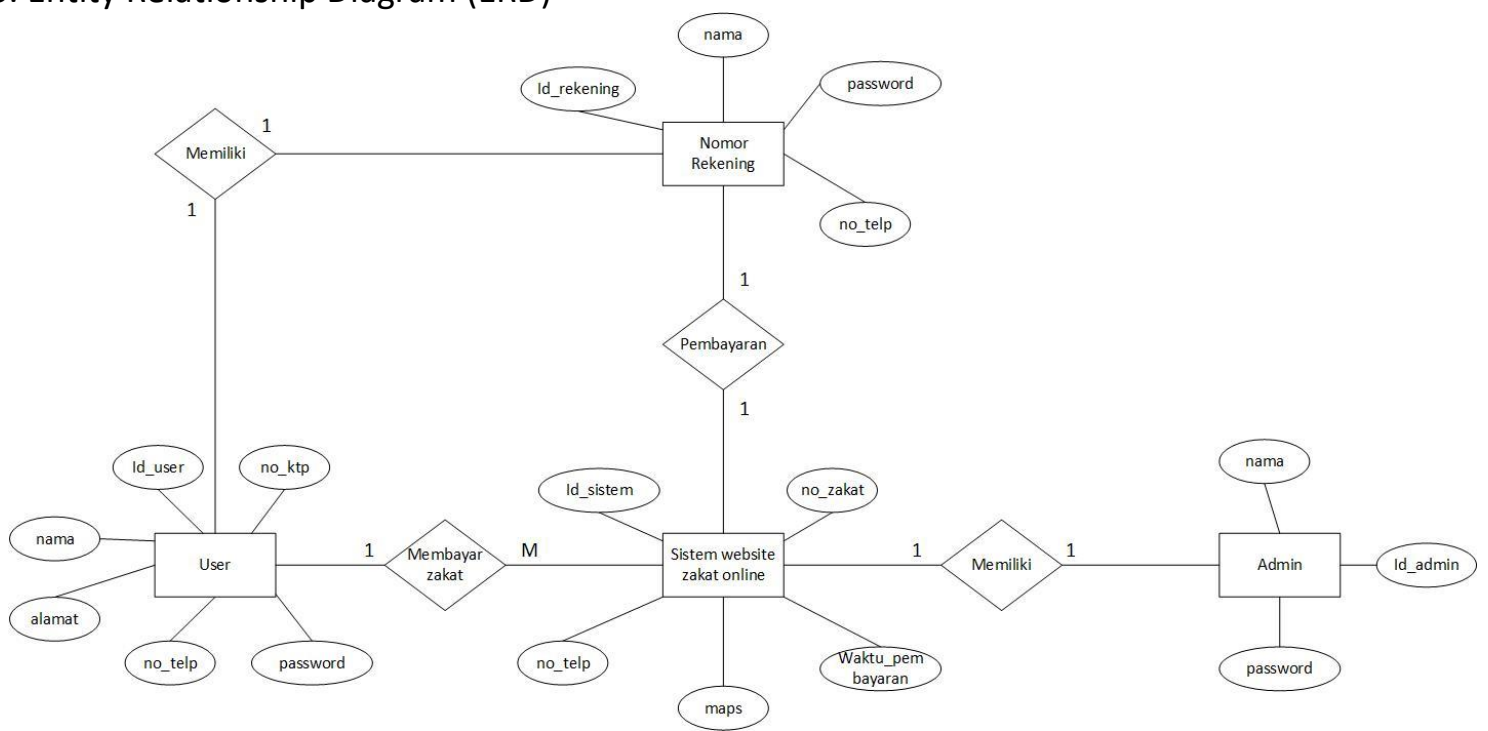

Figure 6 Entity Relationship Diagram 
Gambar diatas merupakan entity relationship diagram dari rancangan website pembayaran zakat online. Entity relationship diagram atau ERD merupakan suatu model yang digunakan untuk merancang database suatu sistem. Dalam ERD tersebut terdapat beberapa entitas seperti nomor rekening, dengan primary key pada atribut id_rekening, entitas user dengan atribut id_user sebagai primary key, entitas sistem website zakat online dengan atribut id_sistem sebagai primary key, dan entitas admin dengan primary key pada atribut id_admin.

\subsection{Database Design}

Berikut ini merupakan database dari rancangan sistem informasi website pembayaran zakat online:

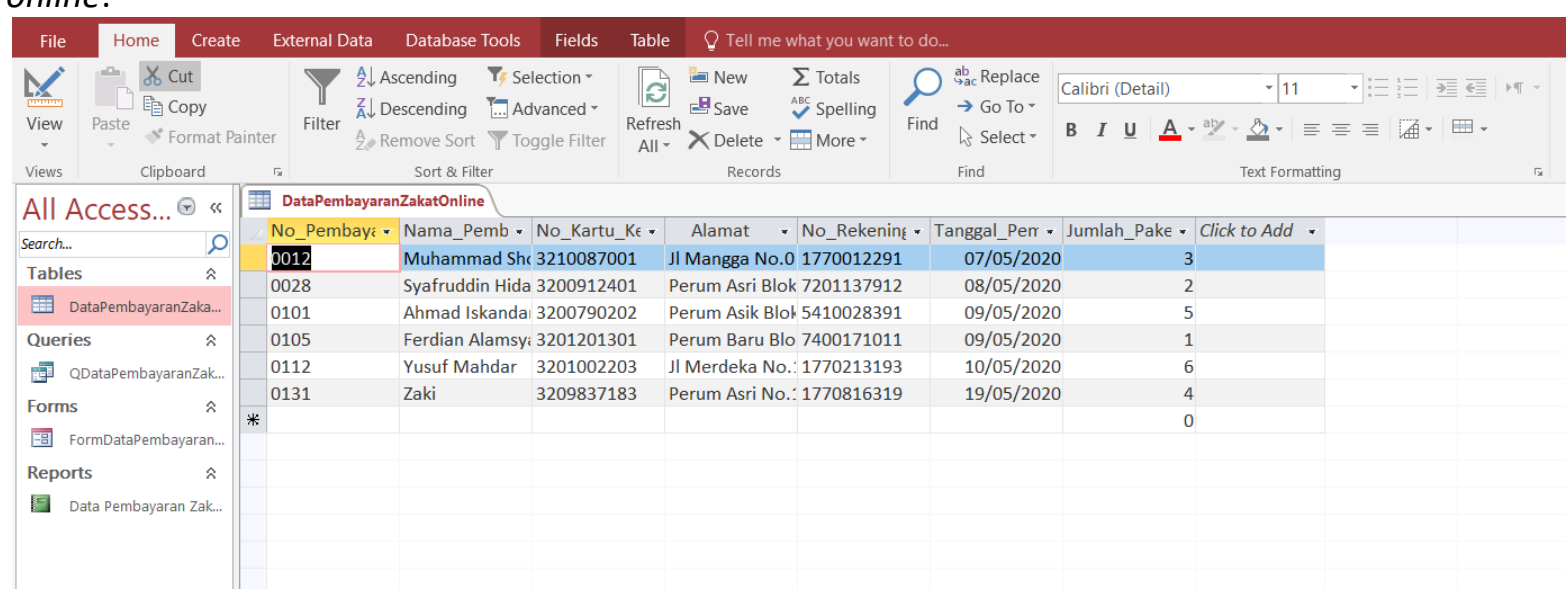

Figure 7 rancangan database

Dalam rancangan database tersebut terdapat kolom no pembayaran, nama pembayar, nomor kartu keluarga, alamat, nomor rekening, tanggal pembayaran, serta jumlah paket pembayaran. Yang semua komponen tersebut wajib diisi.

Berikut merupakan query dari rancangan sistem informasi website pembayaran zakat online:

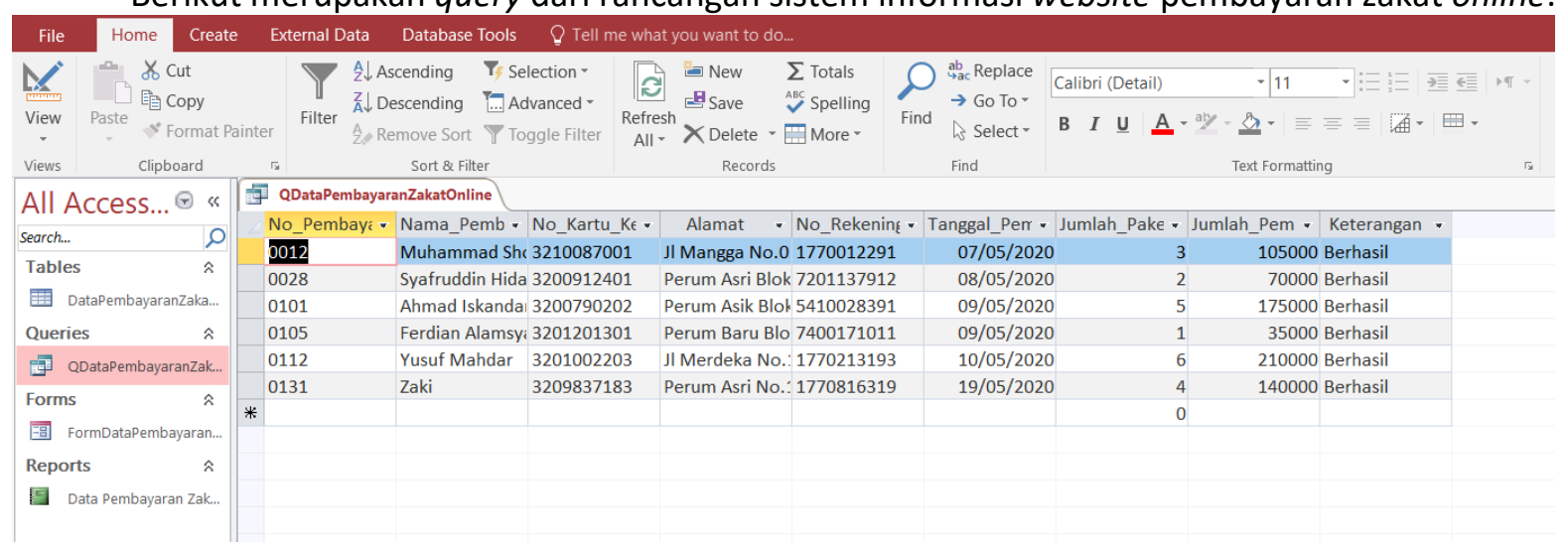

Figure 8 Rancangan Query

Dalam query tersebut terdapat kolom tambahan yaitu kolom keterangan, yang menandakan status pembayaran zakat yang telah dilakukan sudah berhasil atau gagal.

\subsection{Use Case Diagram}

Gambar dibawah ini merupakan use case diagram dari rancangan website pembayaran zakat online. Dimana pengguna website bisa melihat menu info zakat yang didalamnya terdapat informasi mengenai informasi zakat, niat zakat, dan jenis zakat. Selain itu pengguna bisa memilih menu pembayaran zakat dan terdapat dua pilihan pembayaran yaitu pembayaran zakat fitrah serta pembayaran zakat mal. Terdapat juga pilhan cara pembayaran zakat bagi pengguna untuk 
mempermudah proses pembayaran zakat melalui website zakat online ini. Dan yang terakhir pengguna bisa melihat daftar orang yang berhak menerima zakat.

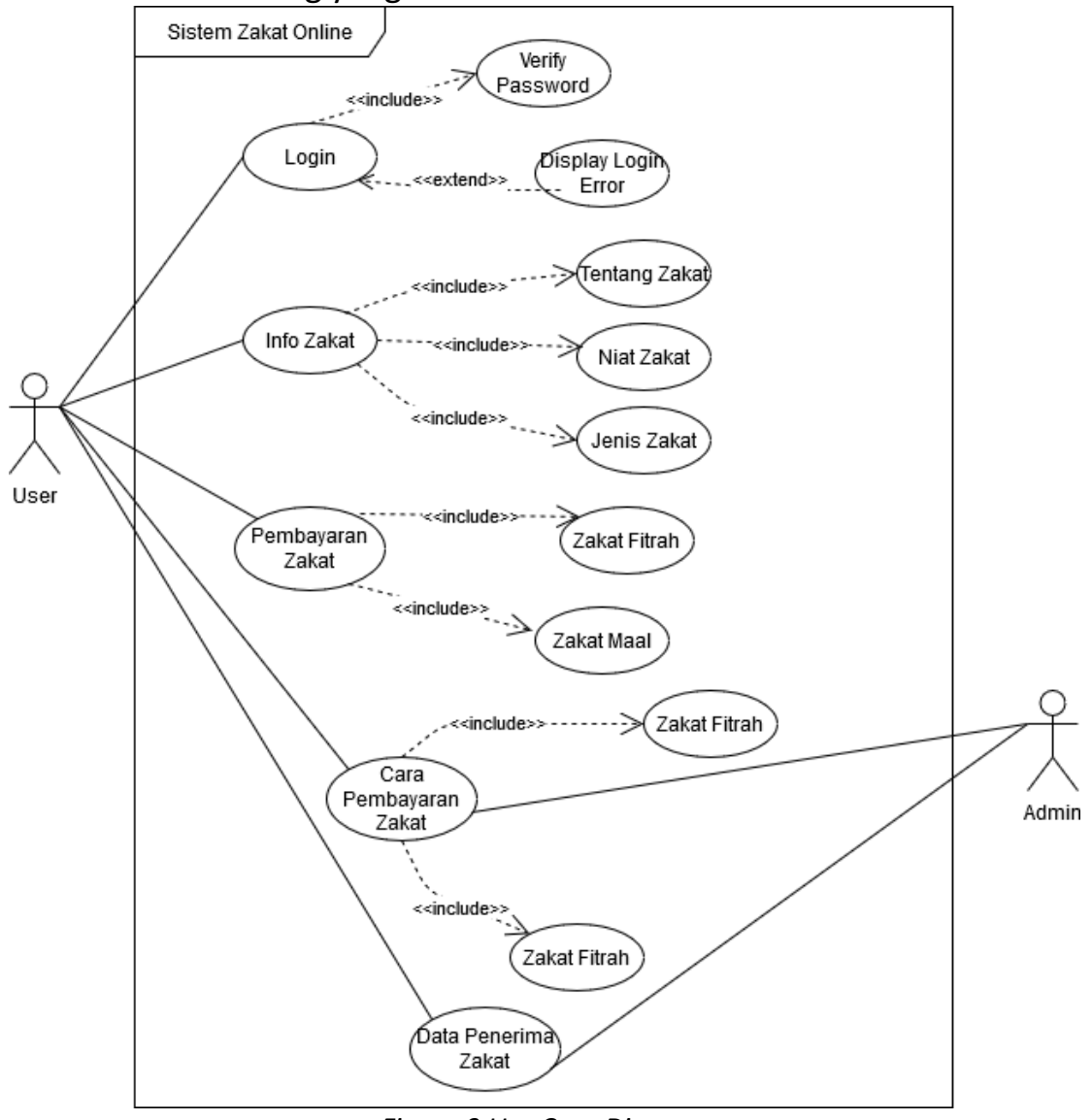

Figure 9 Use Case Diagram

\subsection{Activity Diagram}

Gambar dibawah ini merupakan activity diagram dari proses pembayaran zakat fitrah secara online. Dimana user pertama-tama membuka website zakat online, kemudian login dengan menggunakan username dan password yang telah didaftarkan sebelumnya. Apabila login telah berhasil, maka sistem akan menampilkan tampilan awal dari website, dan kemudian user akan memilih menu pembayaran zakat. Setelah itu system akan menampilkan pilihan menu pembayaran zakat, dan user memilih pembayaran zakat online. Kemudian sistem akan menampilkan form pembayaran zakat, yang kemudian user mengisi form tersebut. Apabila form pembayaran zakat sudah terisi, maka user selanjutnya menekan tombol submit, dan pembayaran akan diproses serta sistem akan menyimpan data pembayaran tersebut dan proses pembayaran berhasil dan selesai dilakukan. 


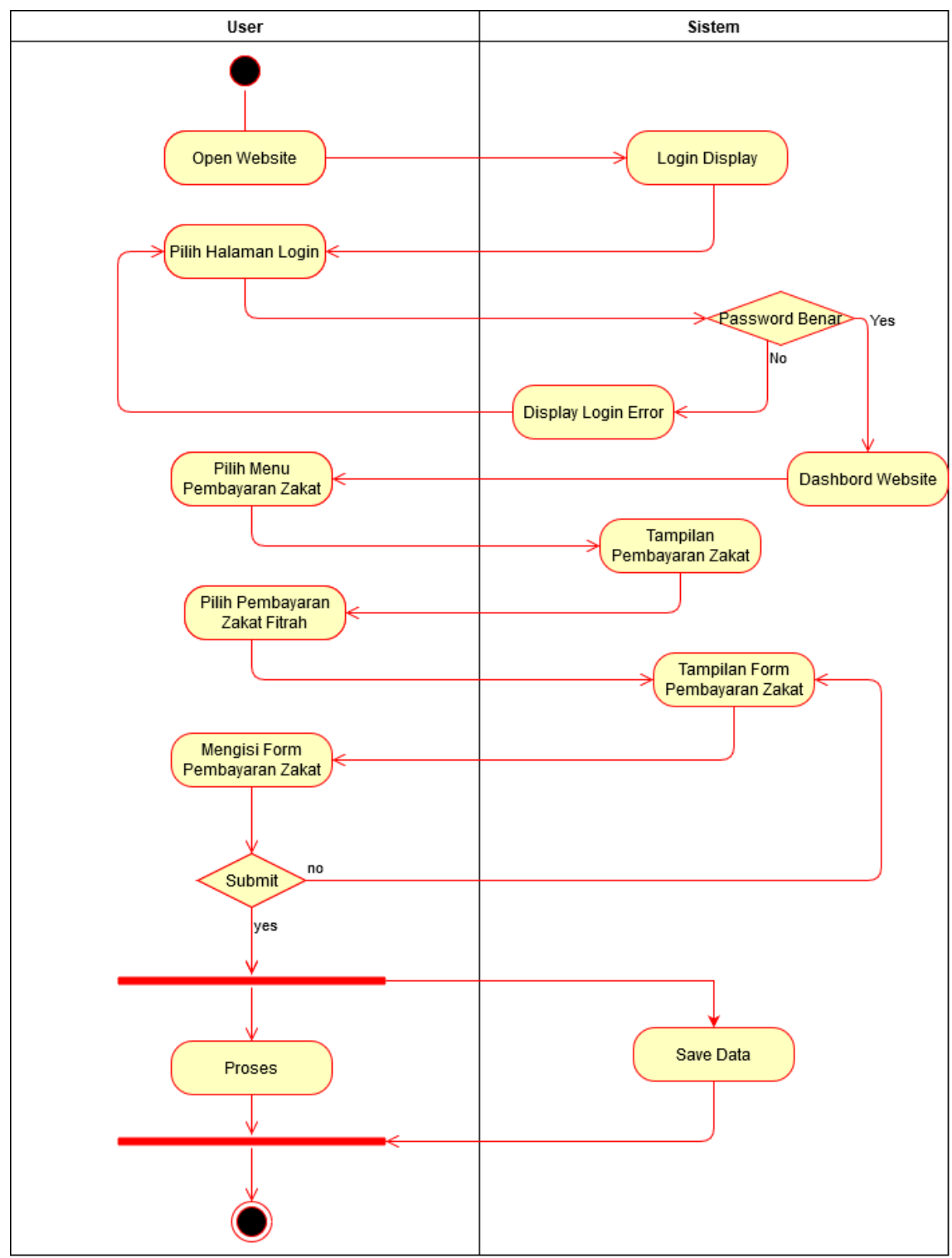

Figure 10 Activity Diagram

\subsection{Sequence Diagram}

Dibawah ini merupakan gambar dari sequence diagram proses login melalui website pembayaran zakat online 


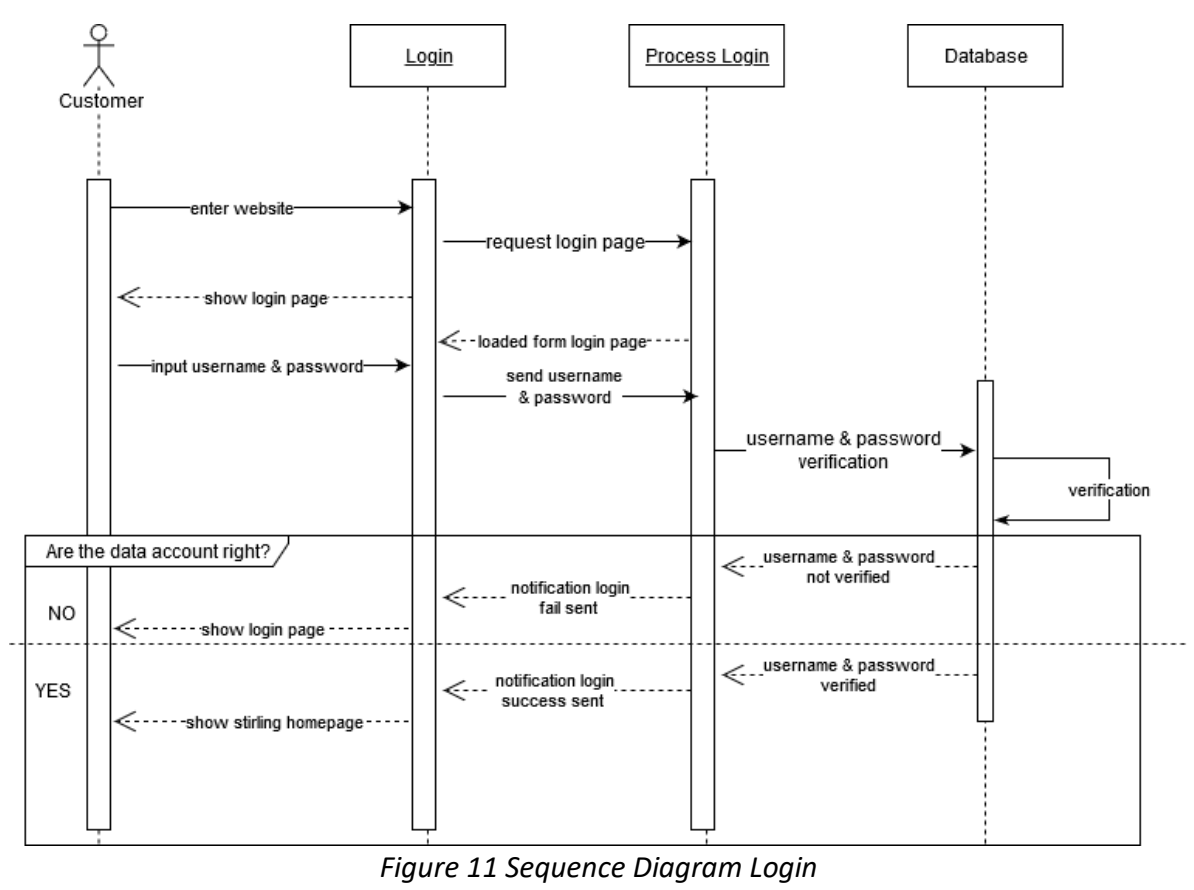

Dibawah ini merupakan gambar dari sequence diagram proses pembayaran zakat fitrah melalui website pembayaran zakat online. Pertama-tama user masuk ke website zakat online terlebih dahulu, kemudian memilih menu pembayaran zakat. Setelah itu user memilih menu pembayaran zakat fitrah, kemudian sistem akan menampilkan form pembayaran yang kemudian akan diisi oleh user. Apabila form pembayaran sudah terisi, maka akan ada proses verifikasi untuk meyakinkan user melakukan pembayaran. Apabila user memilih melanjutkan pembayaran, maka proses pembayaran akan diproses oleh sistem dan data pembayaran akan di simpan di database website. Kemudian apabila pembayaran telah selesai, maka sistem akan menampilkan tampilan pembayaran berhasil.

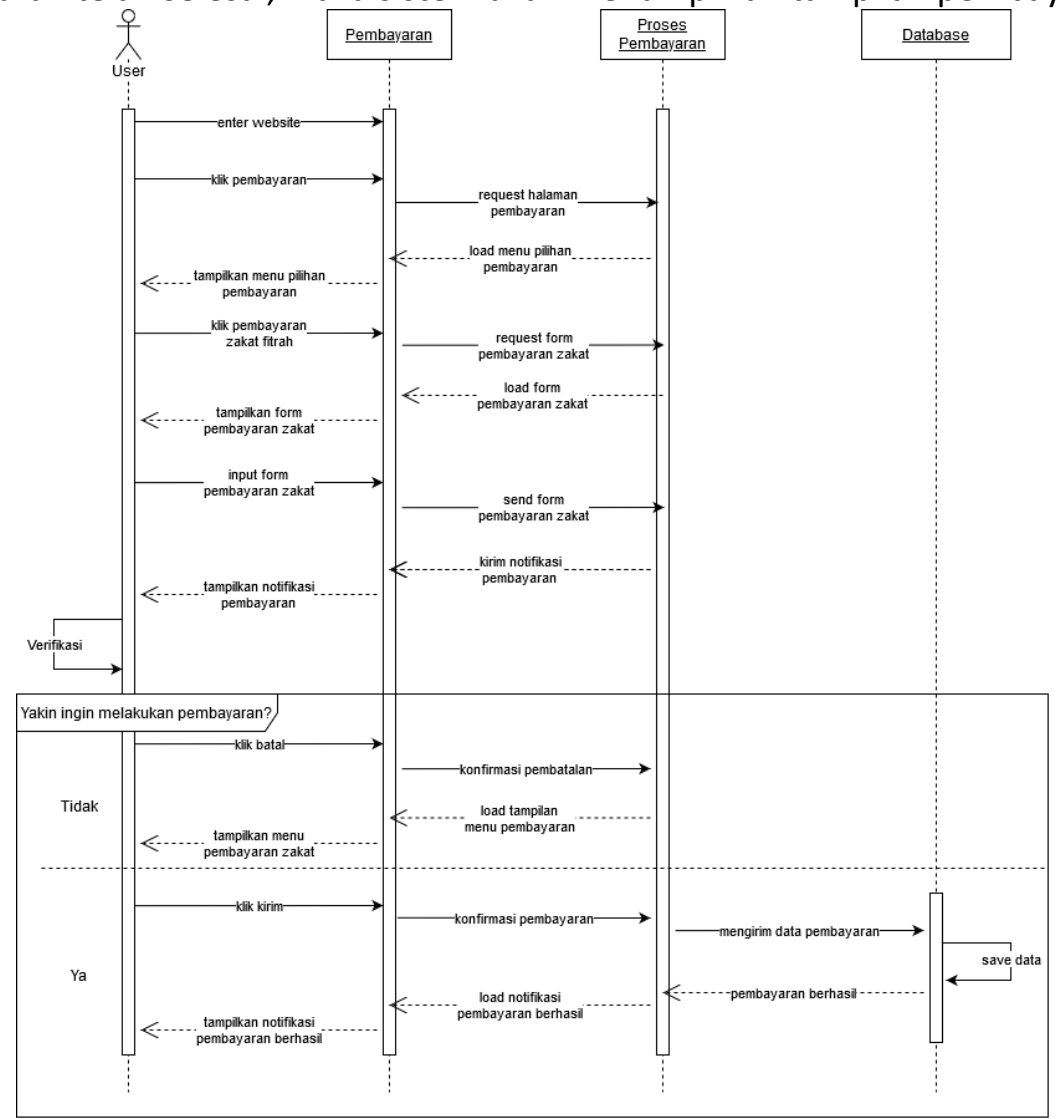

Figure 12 Sequence Diagram Pembayaran 


\subsection{Interface Design}

Berikut merupakan rancangan dan tampilan dari form sistem informasi website pembayaran zakat online:

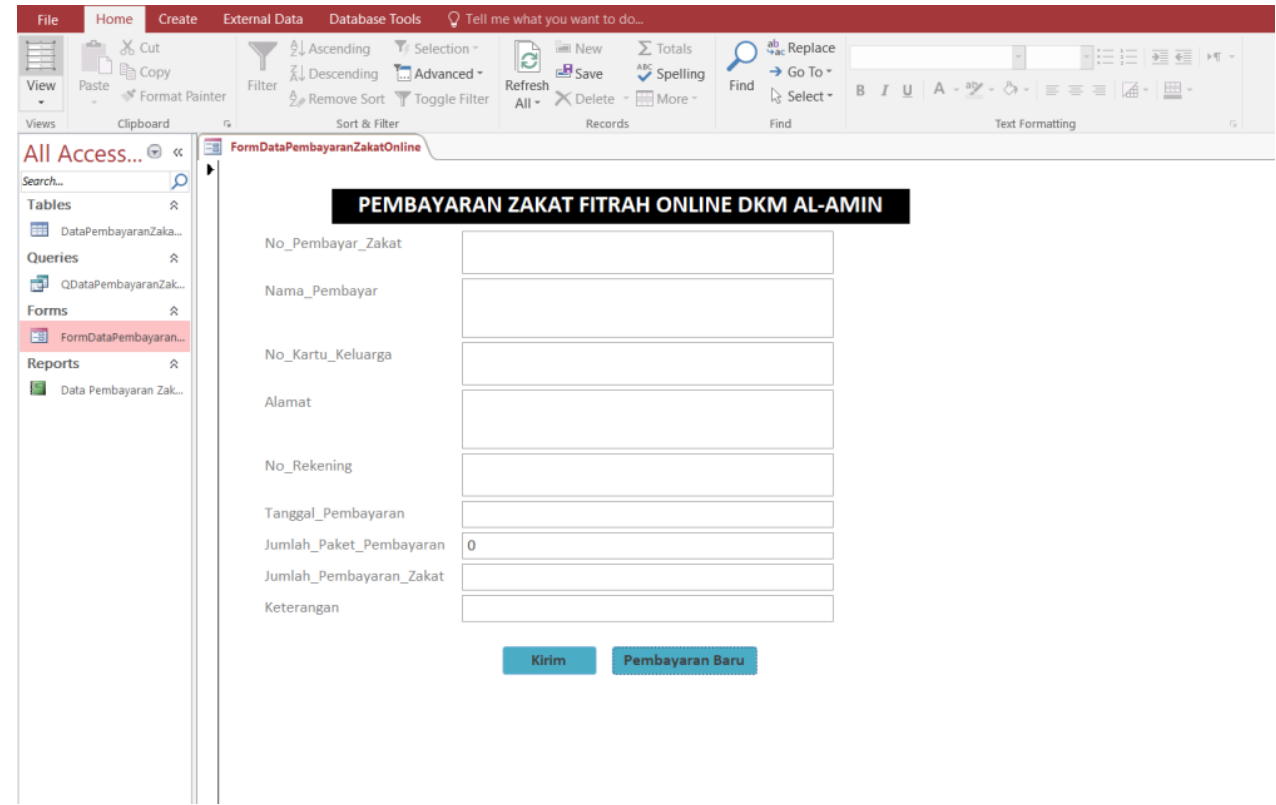

Figure 13 Form Pembayaran

Setiap komponen dalam form tersebut harus diisi mulai dari no pembayaran, nama pembayar, nomor kartu keluarga, alamat, nomor rekening, tanggal pembayaran, serta jumlah paket pembayaran. Akan tetapi jumlah pembayaran zakat dan keterangan akan terisi secara otomatis oleh sistem.

Berikut merupakan report dari hasil pengisian form sistem informasi website pembayaran zakat online:

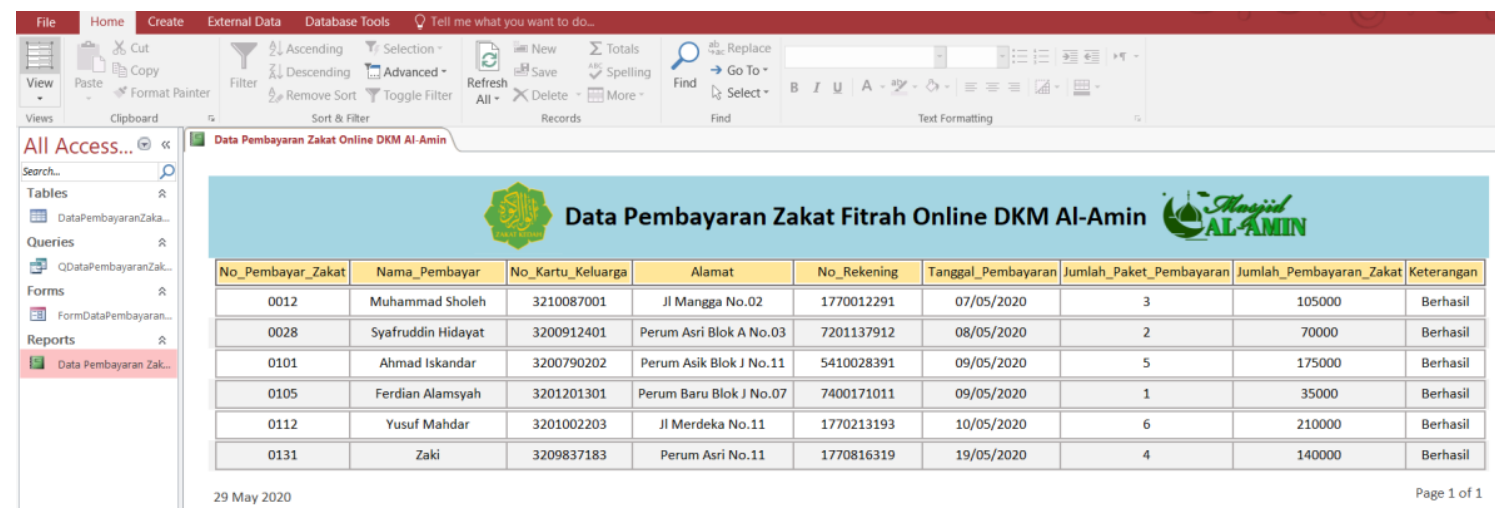

Figure 14 Report Pembayaran

\subsection{Source Code}

Source code didapatkan dari backend file Microsoft Acces database yang telah dibuat. Berikut merupakan tampilan dari backend: 


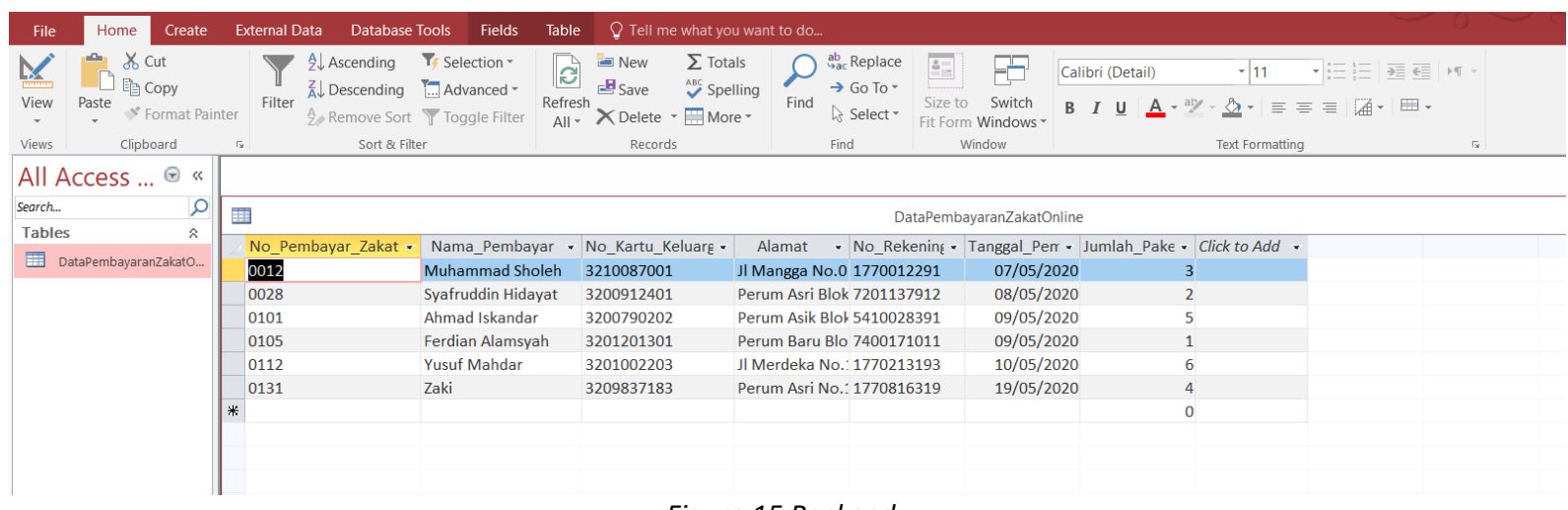

Figure 15 Backend

\section{Penutup}

\subsection{Kesimpulan}

Dengan dibuatnya rancangan sistem informasi website pembayaran zakat online ini, diharapkan dapat berguna bagi panitia penyelenggara zakat dalam memudahkan proses pengelolaan pembayaran dan penyaluran zakat. Selain itu dapat bermanfaat juga bagi orang-orang yang akan membayar zakat, karena dapat mempermudah proses pembayaran zakat tanpa harus mendatangi langsung tempat pembayaran zakat ke masjid atau DKM panitia zakat.

Disisi lainnya dengan adanya system website pembayaran zakat online ini diharapkan dapat meningkatkan jumlah orang yang melakukan pembayaran zakat. Dan juga mampu mendukung program pemerintah dalam menangani wabah covid-19 saaat ini dengan melakukan pembayaran zakat tanpa harus datang ke tempat pembayaran zakat secara langsung.

\subsection{Saran}

Dalam perancangan sistem informasi website pembayaran zakat online ini masih terdapat kekurangan. Maka dari itu diperlukan saran yang sifatnya dapat membangun demi terciptanya sistem informasi website pembayaran zakat online yang lebih baik lagi. Salah satu contohnya adalah dengan menambah fiutr-fitur dalam sistem website zakat tersebut, dan membuat proses pembayaran yang mudah, serta bisa dilakukan kapan saja dan dimana saja. Selain itu juga bisa ditambahkan fitur lain seperti pembayaran shodaqoh dan infaq, sehingga website tersebut tidak hanya melayani pembayaran zakat saja.

\section{References}

[1] T. Aryani, "Pengertian, Hikmah dan Macam-macam Zakat," 08 Maret 2019. [Online]. Available: https://blog.kitabisa.com/pengertian-hikmah-dan-macam-macam-zakat/.

[2] R. Mahanani, "Apa Itu Pandemi dan Perbedaannya dengan Epidemi Terkait Virus Corona," 06 Mei 2020. [Online]. Available: https://kids.grid.id/read/472138667/apa-itu-pandemi-danperbedaannya-dengan-epidemi-terkait-virus-corona?page=all.

[3] d. R. Fadli, "Coronavirus," 25 Mei 2020. [Online]. Available: https://www.halodoc.com/kesehatan/coronavirus.

[4] d. M. D. C. Pane, "Virus Corona (COVID-19)," 26 Mei 2020. [Online]. Available: https://www.alodokter.com/virus-corona.

[5] Waryanto, "Pengertian Website Lengkap dengan Jenis dan Manfaatnya," 22 Januari 2018. [Online]. Available: https://www.niagahoster.co.id/blog/pengertian-website/.

[6] S. Olivia, "DEFINISI DFD (DATA FLOW DIAGRAM)," 01 Oktober 2016. [Online]. Available: https://saraholiviameily.wordpress.com/2016/10/01/definisi-dfd-data-flow-diagram/. 
[7] E. Billah, "Pengertian dan Tahap Metode SDLC Waterfall," 14 Januari 2019. [Online]. Available: https://medium.com/@ersandibillah03/sdlc-waterfall-3a3c893be77b.

Additional

[a] R. Aurachman, "Review Terhadap OSF.IO Sebagai Sarana Publikasi Preprint," OSF Preprints, 17 May 2020. doi:10.31219/osf.io/rvumx , Available: https://osf.io rvumx

[b] R. Aurachman, "Kerangka Perancangan Sistem Informasi Sebagai Pembelajaran Mahasiswa Teknik Industri," osf.io, doi:10.31219/osf.io/tmpcn , 5 2020. Available: https://osf.io/tmpcn 